\title{
PENGARUH VARIABEL MIKRO DAN MAKRO EKONOMI TERHADAP RETURN SAHAM
}

\author{
Kadek Windi Andyani ${ }^{1}$ \\ I Ketut Mustanda ${ }^{2}$ \\ ${ }^{1,2}$ Fakultas Ekonomi dan Bisnis Universitas Udayana (Unud), Bali Indonesia \\ e-mail: windiandyani13@gmail.com
}

\begin{abstract}
ABSTRAK
Penelitian ini bertujuan untuk menjelaskan pengaruh signifikan dari CR, DER, ROE, TATO, EPS, suku bunga, inflasi, dan kurs terhadap return saham. Penelitian ini dilakukan pada perusahaan sektor food and beverage di Bursa Efek Indonesia (BEI) periode 20122016. Jenis data yang digunakan adalah data kuantitatif bersumber dari situs resmi Bursa Efek Indonesia (BEI) dan Bank Indonesia (BI). Jumlah sampel sebanyak 12 perusahaan yang memenuhi kriteria penelitian dengan menggunakan metode purposive sampling. Pengumpulan data menggunakan metode observasi non participan terhadap dokumen berupa laporan keuangan tahunan perusahaan, suku bunga, inflasi dan kurs selama periode 2012-2016. Teknik analisis data yang digunakan adalah analisis regresi linier berganda. Berdasarkan hasil analisis ditemukan bahwa CR, DER memiliki pengaruh negatif dan tidak signifikan terhadap return saham, ROE memiliki pengaruh positif dan signifikan terhadap return saham, TATO, EPS, suku bunga memiliki pengaruh positif dan tidak signifikan terhadap return saham, inflasi, kurs memiliki pengaruh negatif dan signifikan terhadap return saham.
\end{abstract}

Kata kunci: CR, DER, ROE, TATO, EPS, suku bunga, inflasi, nilai kurs, return saham

\begin{abstract}
This study determine the significant effect of CR, DER, ROE, TATO, EPS, interest rate, inflation rate, and exchange rate to stock return. This research was conducted on food and beverage sector companies in Indonesia Stock Exchange (IDX) period 2012-2016. The type of data used is quantitative data sourced from the official website of Indonesia Stock Exchange (IDX) and Bank Indonesia (BI). The number of samples of 12 companies that meet the criteria of research by using purposive sampling method. Data collection use nonparticipant observation method to document in the form of company's annual financial statements, interest rate, inflation and exchange rate during period 2012-2016. Data analysis technique used is multiple linear regression analysis. Based on the analysis result found that CR and DER have negative and insignificant effect to stock return, ROE have positive and significant effect to stock return, TATO, EPS, and positive and insignificant effect on stock return, inflation and exchange rate have negative and significant effect against stock return.
\end{abstract}

Keywords: CR, DER, ROE, TATO, EPS, interest rate, inflation, exchange rate, stock return. 
Kadek Windi Andyani, Pengaruh Variabel Mikro dan...

\section{PENDAHULUAN}

Pasar modal secara umum telah menjadi bagian penting dari pertumbuhan perekonomian Indonesia. Pasar modal adalah suatu pasar untuk memperjualbelikan sekuritas yang umumnya memiliki umur lebih dari satu tahun, seperti saham dan obligasi (Tandelilin, 2010:26). Investasi saham memiliki tingkat pengembalian yang lebih menarik yaitu adanya perubahan harga saham jika harga belinya lebih rendah dari pada harga jual kembali yang sering disebut capital gain. Pasar modal di Indonesia adalah Bursa Efek Indonesia (BEI) yang diharapkan mampu menjadi media pertemuan antara investor dan industri.

Keuntungan yang di peroleh dari investasi dapat dikatakan sebagai return atas saham yang dipilih. Tandelilin (2010:102) return adalah salah satu faktor yang memotivasi investor dalam berinvestasi yang juga merupakan imbalan atas keberanian investor menanggung risiko atas investasi yang dilakukan. Jogiyanto (2011:205) return dapat dibagi menjadi 2 jenis yaitu return ekspektasi (Expected Return) dan return realisasi (Realized Return). Return ekspektasi yaitu return yang diinginkan akan diperoleh oleh investor di masa mendatang. Return realisasi yaitu return yang sudah terjadi dan dapat dihitung dengan menggunakan data historis. Pentingnya return realisasi ini karena dapat digunakan sebagai salah satu alat ukur kinerja dari perusahaan dan berguna sebagai dasar penentuan return ekspektasi serta sebagai penentuan risiko di masa mendatang. Return saham merupakan hasil keuntungan atau kerugian yang didapatkan dari suatu investasi saham. Investor yang ingin berinvestasi dipasar modal umumnya menggunakan analisis teknikal dan fundamental dalam menilai kondisi suatu perusahaan. 
Analisis fundamental menekankan pada kinerja dan proyeksi perusahaan untuk memperkirakan harga saham.

Terdapat banyak perusahaan yang memanfaatkan pasar modal sebagai sumber dananya, salah satunya adalah perusahaan sub sektor food and beverage yang terdaftar di BEI periode 2012-2016. Perusahaan sub sektor food and beverage dipilih karena dilihat dari kondisi perusahaan ini paling stabil dalam masa krisis dibandingkan dengan perusahaan sektor lain, dalam kondisi krisis ataupun tidak makanan dan minuman akan selalu dibutuhkan oleh masyarakat (Nawalani dan Wiwik, 2015). Thendra Chrisnanda (dalam Gideon, 2015) menyatakan bahwa perusahaan sub sektor food and beverage banyak melakukan aktivitas impor atas bahan baku produksi, hal ini berarti berhubungan dengan nilai tukar. Perusahaan sub sektor food and beverage akan terus mengalami pertumbuhan seiring dengan meningkatnya pertumbuhan penduduk.

Data pada Tabel 1. menunjukkan bahwa return saham perusahaan sub sektor food and beverage mengalami fluktuasi setiap tahunnya kecuali pada perusahaan PT Indofood Sukses Makmur Tbk (ICBP), perusahaan tersebut mengalami penurunan setiap tahunnya. Fluktuasi return saham tersebut dapat dipengaruhi oleh beberapa faktor antara lain faktor mikro yang dapat dilihat dari rasio-rasio keuangan seperti likuiditas, leverage, profitabilitas, aktivitas usaha, penilaian pasar dan faktor makro seperti adalah suku bunga, inflasi, nilai kurs, produk domestik bruto (PDB), anggaran defisit, investasi swasta, serta neraca perdagangan dan pembayaran (Tandelilin, 2010:343). Variabel-variabel yang digunakan dilihat dari perbedaan hasil penelitian dari penelitian-penelitian 
sebelumnya, dimana yang digunakan adalah semua rasio-rasio keuangan dan variabel ekonomi makro yang sering diperhatikan oleh investor adalah suku bunga, inflasi dan nilai kurs. Berikut data return saham pada perusahaan sub sektor food and beverage.

Tabel 1.

Return Saham perusahaan sub sektor Food and Beverage yang terdaftar di BEI Periode 2012-2016

\begin{tabular}{ccccccc}
\hline & & \multicolumn{5}{c}{ RETURN SAHAM (\%) } \\
\cline { 3 - 7 } NO & KODE & $\mathbf{2 0 1 2}$ & $\mathbf{2 0 1 3}$ & $\mathbf{2 0 1 4}$ & $\mathbf{2 0 1 5}$ & $\mathbf{2 0 1 6}$ \\
\hline 1 & ADES & 0,90 & 0,04 & $-0,31$ & $-0,26$ & $-0,01$ \\
2 & AISA & 1,18 & 0,32 & 0,47 & $-0,42$ & 0,61 \\
3 & ALTO & - & 0,89 & $-0,38$ & $-0,08$ & 0,02 \\
4 & CEKA & 0,37 & $-0,11$ & 0,29 & $-0,10$ & 1,00 \\
5 & DLTA & 1,29 & 0,49 & 0,03 & $-0,99$ & $-0,04$ \\
6 & ICBP & 0,50 & 0,31 & 0,28 & 0,03 & $-0,36$ \\
7 & INDF & 0,27 & 0,13 & 0,02 & $-0,23$ & 0,53 \\
8 & MLBI & 1,06 & 0,62 & $-0,004$ & $-0,31$ & 0,43 \\
9 & MYOR & 0,40 & 0,52 & $-0,20$ & 0,46 & $-0,95$ \\
10 & PSDN & $-0,34$ & $-0,27$ & $-0,05$ & $-0,15$ & 0,10 \\
11 & ROTI & 1,08 & $-0,26$ & 0,36 & $-0,09$ & 0,26 \\
12 & SKBM & - & 0,23 & 1,02 & $-0,03$ & $-0,32$ \\
13 & SKLT & 0,29 & 0,00 & 0,67 & 0,23 & $-0,17$ \\
14 & STTP & 0,52 & 0,48 & 0,86 & 0,05 & 0,06 \\
15 & ULTJ & 0,23 & 2,38 & $-0,17$ & 0,06 & 0,16 \\
\hline Sumberyyyy$:$ Data & Selnder 2017 & & & & &
\end{tabular}

Sumber: Data sekunder, 2017

Rasio likuiditas yaitu kemampuan perusahaan untuk memenuhi kewajiban finansialnya dalam jangka pendek dengan dana lancar yang tersedia (Wiagustini, 2014:85). Rasio likuiditas terbagi menjadi current ratio (CR), quick ratio (QR), cash ratio, net working capital to sales, dan current assets to sales (Wiagustini, 2014:87). Pada penelitian ini rasio likuiditas yang digunakan adalah current ratio (CR). CR adalah salah satu ukuran likuiditas yang dapat digunakan untuk mengukur kemampuan perusahaan dalam melunasi kewajiban jangka pendeknya 
melalui dana lancar yang dimiliki. CR digunakan karena menunjukkan sejauh mana aktiva lancar menutupi kewajiban lancar. Semakin tinggi CR maka perusahaan dianggap mampu untuk melunasi kewajiban jangka pendeknya sehingga akan menarik investor untuk membeli saham perusahaan dan akan meningkatkan harga saham. CR yang rendah menunjukkan terjadinya masalah dalam likuiditas (Sawir, 2009:10). Penelitian yang dilakukan oleh Aga et al. (2013), Setiyawan (2014) dan Purnamasari dkk. (2014) menunjukkan bahwa CR berpengaruh positif terhadap return saham. Berbeda dengan penelitian yang dilakukan oleh Kadarini (2015), dan Malintan (2012) memiliki hasil yang berbeda yang menunjukkan bahwa CR berpengaruh negatif terhadap return saham.

Rasio leverage merupakan rasio yang dapat menunjukkan hubungan pinjaman jangka panjang yang diberikan oleh kreditur dengan jumlah modal sendiri yang diberikan oleh pemilik perusahaan (Syamsudin, 2009). Rasio leverage terbagi menjadi debt to equity ratio (DER), debt to assets ratio (DAR), long term debt to quity, times interest earned, dan fixed changed coverage (Wiagustini, 2014:87). Pada penelitian ini rasio leverage yang digunakan adalah debt to equity ratio (DER). DER adalah perbandingan atas utang perusahaan terhadap modal sendiri. DER digunakan karena rasio ini mampu menghitung seberapa besar hutang perusahaan dibandingkan modal sendiri yang dimiliki oleh perusahaan. DER menunjukkan perbandingan antara kewajiban perusahaan dengan modal sendiri, semakin tinggi DER maka semakin besar proporsi hutang dalam modal perusahaan yang mana akan menyebabkan risiko investasi yang lebih tinggi (Harahap, 2010:303). Penelitian yang dilakukan oleh Allozi dan 
Obeidat (2016), Bararoh (2015) dan Utami et al. (2015) menunjukkan bahwa DER berpengaruh negatif terhadap return saham. Berbeda dengan penelitian yang dilakukan oleh Abdullah et al. (2015) memiliki hasil yang berbeda yang menunjukkan bahwa DER berpengaruh positif terhadap return saham.

Rasio profitabilitas adalah rasio untuk menilai kemampuan perusahaan dalam mencari keuntungan (Kasmir, 2013:196). Rasio profitabilitas terbagi menjadi profit margin, return on investment (ROI), return on equity (ROE), dan laba per lembar saham (Kasmir, 2013:199). Pada penelitian ini rasio profitabilitas yang digunakan adalah return on equity (ROE). ROE digunakan oleh investor untuk menilai bagaimana prospek suatu perusahaan kedepannya dan investor dapat melihat sejauh mana pertumbuhan profitabilitas perusahaan tersebut. Nilai ROE yang tinggi akan memberikan petunjuk bahwa kinerja perusahaan adalah baik. Semakin tinggi laba bersih setelah pajak, maka semakin tinggi nilai ROE, sehingga akan berdampak pada meningkatnya harga saham perusahaan dan return saham. Penelitian yang dilakukan oleh Khan et al. (2013), Indraswari dan Santi (2013), Wijesundera et al. (2015), Saleh (2015), Har dan Muhammad (2015), Allozi dan Obeidat (2016) serta Haghiri (2012) menunjukkan bahwa ROE berpengaruh positif dan signifikan terhadap return saham. Penelitian yang dilakukan oleh Anwaar (2016) menunjukkan bahwa ROE berpengaruh dan tidak signifikan terhadap return saham. Berbeda dengan penelitian yang dilakukan oleh Nurhakim et al. (2016) dan Pinka Komala (2013) memiliki hasil yang berbeda yang menunjukkan bahwa ROE berpengaruh negatif terhadap return saham. 
Rasio aktivitas usaha adalah rasio yang menggambarkan aktivitas yang dilakukan perusahaan dalam menjalankan operasinya (Harahap, 2010:301). Rasio aktivitas usaha terbagi menjadi total assets turn over, fixed assets turnover, receivable turnover, working capital turnover (Kasmir, 2012:175). Pada penelitian ini rasio aktivitas usaha yang digunakan adalah total assets turn over (TATO). TATO adalah perbandingan antara penjualan dengan total aktiva suatu perusahaan. TATO digunakan untuk mengukur efektivitas penggunaan total aktiva dalam rangka mencapai penjualan. TATO yang tinggi menunjukkan bahwa manajemen perusahaan dapat menggunakan seluruh aktiva yang dimilikinya untuk mendapatkan revenue bagi perusahaan dan hal ini dianggap dapat meningkatkan keuntungan perusahaan. TATO yang tinggi dapat berpotensi menarik investor untuk berinvestasi pada perusahaan tersebut yang kemudian akan berdampak pada harga saham Thrisye dan Nicodemus (2013). Penelitian yang dilakukan oleh Bararoh (2015), Kurniatun dkk. (2015) menunjukkan bahwa TATO berpengaruh positif dan signifikan terhadap return saham. Berbeda dengan penelitian yang dilakukan oleh Ulupui (2007), Farkhan dan Ika (2012) menunjukkan bahwa TATO berpengaruh negatif dan tidak signifikan terhadap return saham.

Rasio penilaian pasar yaitu pengakuan terhadap kondisi keuangan yang dicapai perusahaan atau mengukur kemampuan manajemen dalam menciptakan nilai pasarnya diatas biaya investasi (Wiagustini, 2014:86). Rasio penilaian pasar terbagi menjadi earning per share (EPS), price earining ratio (PER), market to book value, price to cash fow ratio, dan dividend payout ratio (Wiagustini, 
Kadek Windi Andyani, Pengaruh Variabel Mikro dan...

2014:90). Pada penelitian ini rasio aktivitas usaha yang digunakan adalah earning per share (EPS). EPS digunakan untuk menganalisis kemampuan dari perusahaan untuk mendapat laba dari saham yang dipilih. Nilai EPS yang tinggi menunjukkan kinerja perusahaan yang baik, sehingga dapat menarik minat bagi investor untuk menginvestasikan dananya pada perusahaan, hal ini berarti jika EPS yang diberikan semakin besar maka akan berdampak pada meningkatnya harga saham perusahaan serta return saham perusahaan. Penelitian yang dilakukan oleh Allozi dan Obeidat (2016), serta Utami et al. (2015) menunjukkan hasil bahwa EPS berpengaruh positif terhadap return saham. Berbeda dengan penelitian yang dilakukan oleh Anwaar (2016), Salamat dan Mustafa (2016) menunjukkan bahwa EPS berpengaruh negatif terhadap return saham.

Suku bunga adalah harga atas dana yang dipinjam oleh perusahaan. Tingkat suku bunga yang tinggi merupakan sinyal negatif terhadap harga saham (Tandelilin, 2010:343). Tingkat suku bunga yang terlalu tinggi akan mempengaruhi nilai sekarang (present value) aliran kas perusahaan sehingga kesempatan-kesempatan investasi yang ada tidak akan menarik lagi. Tingkat suku bunga yang tinggi juga menyebabkan investor menarik investasinya pada saham dan memindahkannya pada investasi berupa tabungan ataupun deposito. Bank Indonesia memiliki kewenangan untuk menetapkan tingkat suku bunga yang dikenal dengan BI Rate. Bank-bank di Indonesia harus melihat suku bunga BI sebagai dasar dalam menetapkan bunga pinjaman maupun bunga simpanan (deposito). Penelitian yang dilakukan oleh Utami et al. (2015) dan Krisna (2013) menunjukkan bahwa suku bunga berpengaruh negatif terhadap return saham. 
Berbeda dengan penelitian yang dilakukan oleh Oshaibat dan Majali (2016), Bararoh (2015), dan Khan et al. (2012) menunjukkan bahwa suku bunga berpengaruh positif terhadap return saham.

Inflasi adalah kecenderungan terjadinya peningkatan harga produk-produk secara keseluruhan sehingga terjadinya penurunan daya beli uang (Tandelilin, 2010:342). Inflasi yang tinggi biasanya terjadi akibat kondisi ekonomi yang overheated. Hal ini berarti apabila kondisi ekonomi sedang mengalami permintaan produk yang melebihi kapasitas penawaran produknya akan mengakibatkan terjadinya kenaikan harga produk keseluruhan (Bodie, dkk. 2009:178). Inflasi memiliki dampak negatif terhadap harga saham karena inflasi meningkatkan biaya suatu perusahaan, apabila peningkatan biaya lebih tinggi dari pada pendapatan perusahaan, maka profitabilitas perusahaan tersebut akan mengalami penurunan. Penurunan laba dari perusahaan akan menyebabkan investor tidak tertarik untuk berinvestasi'pada perusahaan, hal ini dapat mengakibatkan penurunan harga saham dan akan berdampak pada return saham (Tandelilin, 2010:343). Kondisi seperti ini menyebabkan inflasi berpengaruh negatif terhadap return saham. Penelitian yang dilakukan Nurhakim et al. (2016), Utami et al. (2015), Khan et al. (2012), Zhu Bing (2012), dan Karim (2015) menunjukkan bahwa inflasi berpengaruh negatif terhadap return saham. Penelitian lain dilakukan oleh Khaza'leh dan Alrguibat (2014), Oshaibat dan Majali (2016), dan Ibrahim dan Agbaje (2013) menunjukkan bahwa inflasi berpengaruh positif terhadap return saham. 
Kurs adalah nilai suatu mata uang relatif terhadap mata uang lain (Hanafi, 2014:226). Depresiasi kurs mata uang domestik terhadap mata uang asing dapat meningkatkan volume ekspor. Hal ini dapat meningkatkan profitabilitas perusahaan yang kemudian meningkatkan harga saham perusahaan apabila permintaan pada pasar internasional cukup elastis dan mempengaruhi return yang akan diterima oleh investor (Kewal, 2012). Depresiasi kurs mata uang domestik dapat memberi dampak negatif terhadap emiten yang memiliki hutang dalam mata uang asing sedangkan produk emiten tersebut dijual didalam negeri. Hal tersebut mengakibatkan penurunan harga saham emiten di BEI yang berakibat terhadap penurunan return saham (Samsul, 2006:202). Penelitian yang dilakukan oleh Utami et al. (2015), Bararoh (2015) menunjukkan bahwa nilai kurs berpengaruh positif terhadap return saham. Penelitian lain yang dilakukan oleh Khan et al. (2012), dan Octafia (2013) memiliki hasil berbeda yang menunjukkan bahwa nilai kurs berpengaruh negatif terhadap return saham.

Berdasarkan hasil studi empiris ditemukan adanya perbedaan hasil penelitian yang menjadi riset gap dalam penelitian ini serta adanya fenomena return saham pada perusahaan sub sektor food and beverage yang terdaftar di BEI periode 2012-2016, maka penelitian ini dilakukan untuk meneliti kembali dengan tujuan memperjelas penemuan sebelumnya dengan meneliti pengaruh faktor mikro dan makro ekonomi terhadap return saham perusahaan food and beverage di BEI periode 2012-2016.

Berdasarkan latar belakang masalah yang telah diuraikan diatas, maka pokok permasalahan pada penelitian ini adalah apakah likuiditas, leverage, 
profitabilitas, aktivitas usaha, penilaian pasar, suku bunga, inflasi, dan nilai kurs berpengaruh signifikan terhadap return saham? Dari rumusan masalah tersebut, maka tujuan pada penelitian ini adalah untuk menjelaskan signifikansi pengaruh likuiditas, leverage, profitabilitas, aktivitas usaha, penilaian pasar, suku bunga, inflasi, dan nilai kurs terhadap return saham.

Penelitian ini memberikan manfaat teoritis dengan harapan hasil penelitian mampu memberikan kontribusi empiris terkait dengan pengaruh variabel mikro dan makro ekonomi terhadap return saham. Penelitian ini juga memberikan manfaat praktis dengan harapan hasil penelitian ini dapat berguna bagi pihak perusahaan sebagai bahan masukan dan pertimbangan dalam mengambil keputusan yang berdampak terhadap return saham perusahaan.

Menurut Wiagustini (2014:25) pasar modal (capital market) disusun untuk investasi jangka panjang. Penggunaan pasar modal ini merupakan individuindividu, pemerintah, serta organisasi laba dan non laba. Return saham adalah hasil yang didapatkan dari investasi. Menurut Tandelilin (2010:102) return saham adalah salah satu faktor yang memotivasi investor dalam berinvestasi yang juga merupakan imbalan atas keberanian investor menanggung risiko atas investasi yang dilakukan. Sumber-sumber return terdiri dari dua komponen diantaranya adalah yield dan capital gain (loss).

Rasio likuiditas yaitu kemampuan perusahaan untuk memenuhi kewajiban finansialnya dalam jangka pendek dengan dana lancar yang tersedia (Wiagustini, 2014:85). Alat ukur dalam penelitian ini adalah CR. CR digunakan karena menunjukkan sejauh mana aktiva lancar menutupi kewajiban lancar. Semakin 
Kadek Windi Andyani, Pengaruh Variabel Mikro dan...

tinggi CR maka perusahaan dianggap mampu untuk melunasi kewajiban jangka pendeknya sehingga akan menarik investor untuk membeli saham perusahaan, akibatnya akan meningkatkan harga saham. Sebaliknya CR yang rendah biasanya dianggap menunjukkan terjadinya masalah dalam likuiditas (Sawir, 2009:10). CR sangat penting karena kegagalan perusahaan dalam memenuhi kewajiban jangka pendeknya akan membawa perusahaan ke arah kebangkrutan. Return saham yang tinggi akan diperoleh jika perusahaan mampu memenuhi kewajiban jangka pendeknya. Penelitian yang dilakukan oleh Aga et al. (2013), Setiyawan (2014) dan Purnamasari dkk. (2014) diketahui bahwa CR memiliki pengaruh positif terhadap return saham. Dari hasil studi empiris tersebut, maka hipotesis yang dapat dirumuskan adalah :

$\mathrm{H}_{1}$ : CR memiliki pengaruh positif dan signifikan terhadap return saham.

Rasio leverage merupakan rasio yang dapat menunjukkan hubungan pinjaman jangka panjang yang diberikan oleh kreditur dengan jumlah modal sendiri yang diberikan oleh pemilik perusahaan (Syamsudin, 2009). Alat ukur dalam penelitian ini adalah DER. DER digunakan karena mampu menghitung seberapa besar hutang perusahaan dibandingkan modal yang dimiliki oleh perusahaan atau para pemegang saham. Harahap (2010:303) DER menunjukkan perbandingan antara kewajiban perusahaan dengan modal sendiri, semakin tinggi DER maka semakin besar proporsi hutang dalam modal perusahaan yang mana akan menyebabkan risiko investasi yang lebih tinggi. Penelitian yang dilakukan oleh Allozi dan Obeidat (2016), Bararoh (2015), Utami et al. (2015) yang 
diketahui bahwa DER memiliki pengaruh negatif terhadap return saham. Dari hasil studi empiris tersebut, maka hipotesis yang dapat dirumuskan adalah :

$\mathrm{H}_{2}$ : DER memiliki pengaruh negatif dan signifikan terhadap return saham.

Rasio profitabilitas adalah rasio untuk menilai kemampuan perusahaan dalam mencari keuntungan (Kasmir, 2013:196). Alat ukur dalam penelitian ini adalah ROE. ROE digunakan karena mampu menerangkan bagaimana laba dapat diperoleh pemegang saham melalui kemampuan dan modal sendiri yang dimiliki perusahaan. Nilai ROE yang tinggi akan memberikan petunjuk bahwa kinerja perusahaan adalah baik. Semakin tinggi laba bersih setelah pajak, maka semakin tinggi nilai ROE, sehingga akan berdampak pada meningkatnya harga saham perusahaan dan return saham. Penelitian yang dilakukan oleh Anwaar (2016), Allozi dan Obeidat (2016), Haghiri (2012) yang menunjukkan bahwa ROE memiliki pengaruh positif terhadap return saham. Dari hasil studi empiris tersebut, maka hipotesis yang dapat dirumuskan adalah :

$\mathrm{H}_{3}$ : ROE memiliki pengaruh positif dan signifikan terhadap return saham.

Rasio aktivitas usaha adalah rasio yang menggambarkan aktivitas yang dilakukan perusahaan dalam menjalankan operasinya (Harahap, 2010:301). Alat ukur dalam penelitian ini adalah TATO. TATO digunakan karena rasio ini dapat mengukur seberapa optimal kemampuan perusahaan menghasilkan penjualan berdasarkan seluruh aktiva yang dimilikinya atau perputaran aktiva-aktiva tersebut. TATO yang tinggi berpotensi menarik investor untuk terus berinvestasi di perusahaan tersebut dan akan meningkatkan nilai saham tersebut. TATO yang tinggi menunjukkan efektivitas suatu perusahaan dalam memanfaatkan aktiva 
yang dimilikinya yang kemudian akan berdampak positif pada harga saham (Thrisye dan Nicodemus, 2013). Penelitian yang dilakukan oleh Bararoh (2015), Kurniatun dkk. (2015) menunjukkan bahwa TATO berpengaruh positif dan signifikan terhadap return saham. Dari hasil studi empiris tersebut, maka hipotesis yang dapat dirumuskan adalah :

$\mathrm{H}_{4}$ : TATO memiliki pengaruh positif dan signifikan terhadap return saham.

Rasio penilaian pasar yaitu pengakuan terhadap kondisi keuangan yang dicapai perusahaan atau mengukur kemampuan manajemen dalam menciptakan nilai pasarnya diatas biaya investasi (Wiagustini 2014:86). Alat ukur dalam penelitian ini adalah EPS. EPS merupakan daya tarik suatu perusahaan untuk menarik minat investor. Nilai EPS yang tinggi menunjukkan kinerja perusahaan baik, sehingga dapat menarik minat bagi investor untuk menginvestasikan dananya pada perusahaan, karena jika EPS yang diberikan semakin besar maka akan berdampak pada meningkatnya harga saham perusahaan serta return saham perusahaan. Penelitian yang dilakukan oleh Alozzi dan Obeidat (2016), dan Utami et al. (2015) yang menyatakan bahwa EPS memiliki pengaruh positif terhadap return saham. Dari hasil studi empiris tersebut, maka hipotesis yang dapat dirumuskan adalah :

$\mathrm{H}_{5}$ : EPS memiliki pengaruh positif dan signifikan terhadap return saham.

Suku bunga adalah harga atas dana yang dipinjam oleh perusahaan. Suku bunga akan berdampak pada perubahan jumlah investasi. Tingkat suku bunga yang tinggi juga menyebabkan investor menarik investasinya pada saham dan memindahkannya pada investasi berupa tabungan ataupun deposito. Suku bunga 
SBI adalah instrument suku bunga yang dikeluarkan oleh BI untuk mengontrol peredaran uang di masyarakat. Bank Indonesia dapat menyerap kelebihan uang yang beredar dengan menjual SBI. Penelitian yang dilakukan oleh Utami et al. (2015) dan Al Oshaibat (2016) yang menunjukkan bahwa suku bunga berpengaruh negatif terhadap return saham. Dari hasil studi empiris tersebut, maka hipotesis yang dapat dirumuskan adalah :

$\mathrm{H}_{6}$ : Suku bunga memiliki pengaruh negatif dan signifikan terhadap return saham.

Secara relatif inflasi berpengaruh negatif terhadap return saham (Tandelilin,2010:343). Inflasi tinggi dapat mengurangi tingkat pendapatan riil yang diperoleh oleh investor dari investasi. Inflasi suatu negara mengalami penurunan maka ini adalah sinyal yang positif bagi para investor seiring dengan turunnya risiko daya beli uang serta risiko penurunan pendapatan riil. Meningkatnya inflasi akan berdampak pada peningkatan harga jual dan biaya produksi perusahaan. Biaya produksi meningkat lebih tinggi daripada peningkatan penjualan perusahaan, maka profitabilitas perusahaan akan mengalami penurunan yang berakibat terhadap penurunan tingkat return saham, demikian juga sebaliknya. Penelitian yang dilakukan oleh Nurhakim S (2016), Karim (2015), Nasir (2011) yang menunjukkan bahwa inflasi berpengaruh negatif terhadap return saham. Dari hasil studi empiris tersebut, maka hipotesis yang dapat dirumuskan adalah :

$\mathrm{H}_{7}$ : Inflasi memiliki pengaruh negatif dan signifikan terhadap return saham.

Nilai kurs adalah nilai suatu mata uang relatif terhadap mata uang lain (Hanafi, 2014:226). Perubahan nilai tukar suatu mata uang akan dipengaruhi oleh 
Kadek Windi Andyani, Pengaruh Variabel Mikro dan...

suatu permintaan dan penawaran mata uang tersebut. Nilai kurs mata uang domestik yang menguat terhadap mata uang asing adalah sinyal positif bagi perekonomian yang sedang mengalami inflasi. Menguatnya nilai kurs mata uang domestik terhadap mata uang asing akan menurunkan biaya impor bahan baku untuk produksi dan akan menurunkan nilai suku bunga yang berlaku. Tandelilin (2010:344) menunjukkan bahwa nilai kurs berdampak positif terhadap return saham. Penelitian yang dilakukan oleh Utami et al. (2015), Bararoh (2015), Karim (2015), Handiani (2014) menunjukan bahwa nilai kurs berpengaruh positif terhadap return saham. Dari hasil studi empiris tersebut, maka hipotesis yang dapat dirumuskan adalah :

$\mathrm{H}_{8}$ : Nilai kurs memiliki pengaruh positif dan signifikan terhadap return saham.

Berdasarkan kajian pustaka dan hasil studi empiris, maka dapat dibuat kerangka konseptual penelitian ini pada Gambar 2.

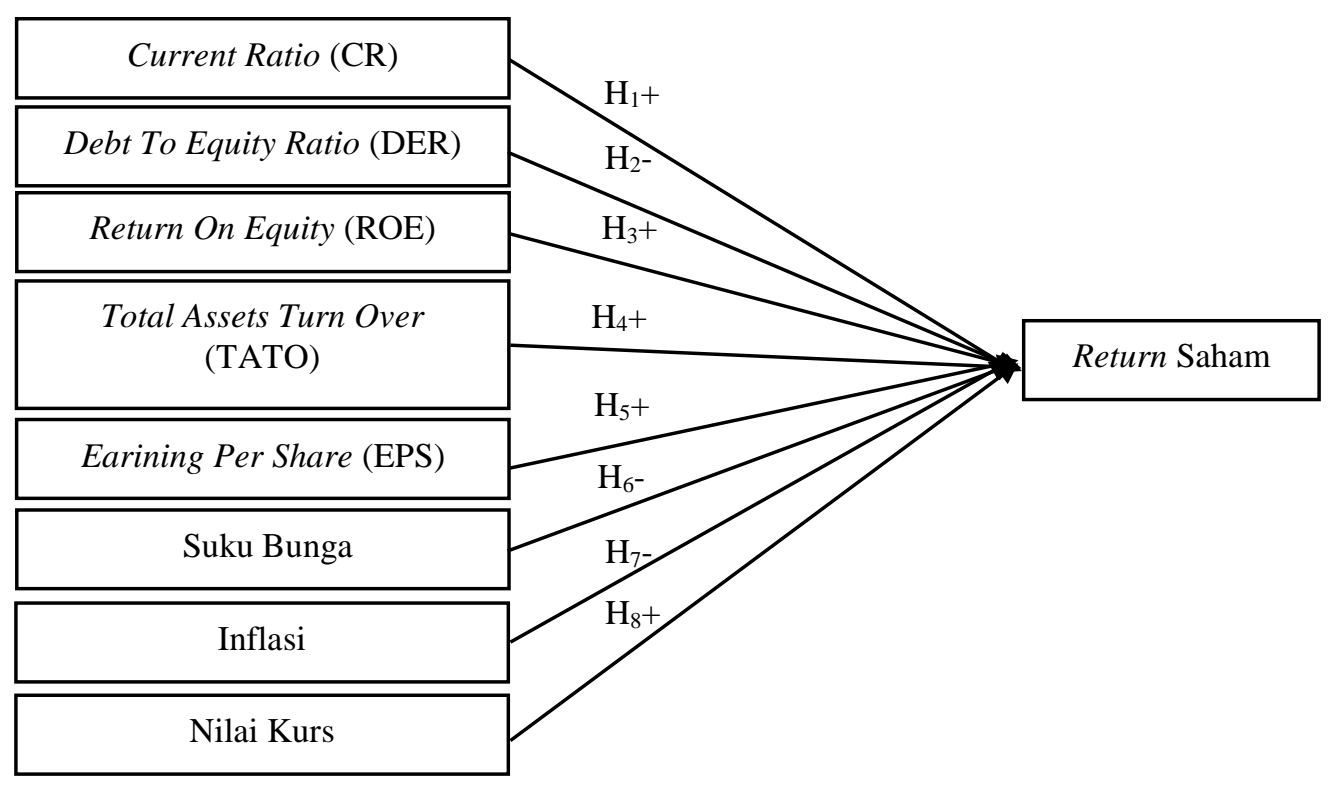

Gambar 2. Kerangka Konseptual Penelitian 


\section{METODE PENELITIAN}

Penelitian dilakukan pada perusahaan sub sektor food and beverage yang terdaftar di BEI periode 2012-2016. Objek penelitian yang digunakan adalah return saham pada perusahaan sub sektor food and beverage di BEI periode 20122016. Jenis data yang digunakan dalam penelitian ini adalah data kuantitatif, berupa data yang diperoleh dari sumber laporan keuangan yang dipublikasikan dalam www.idx.co.id serta return saham yang dipublikasikan dalam www.duniainvestasi.com periode tahun 2012-2016. Populasi pada penelitian ini adalah seluruh perusahaan sub sektor food and beverage di BEI periode 20122016 yang berjumlah 15 perusahaan. Metode yang digunakan dalam penentuan sampel adalah metode purposive sampling yaitu penentuan sampel dengan menentukan kriteria-kriteria tertentu. Kriteria tersebut berupa perusahaan yang melakukan aktivitas perdagangan saham sesuai periode tahun penelitian. Berdasarkan kriteria tersebut, dari 15 perusahaan yang terdaftar hanya 12 perusahaan yang memenuhi kriteria sampel. Teknik pengujian data menggunakan uji asumsi klasik sedangkan untuk teknik analisis data, digunakan model regresi linier berganda untuk menguji pengaruh variabel X terhadap Y.

\section{HASIL DAN PEMBAHASAN}

Analisis regresi linier berganda betujuan untuk mengetahui pengaruh dari CR, DER, ROE, TATO, EPS, suku bunga, inflasi, nilai kurs terhadap yaitu return saham. Hasil analisis regresi linier berganda dapat dilihat pada Tabel 2. sebagai berikut: 
Tabel 2.

Hasil Analisis Regresi Linier Berganda

\begin{tabular}{|c|c|c|c|c|c|}
\hline \multirow[t]{2}{*}{ Model } & \multicolumn{2}{|c|}{ Unstandardized Coefficients } & \multirow{2}{*}{$\begin{array}{c}\begin{array}{c}\text { Standardized } \\
\text { Coefficients }\end{array} \\
\text { Beta }\end{array}$} & \multirow[t]{2}{*}{$\mathrm{t}$} & \multirow[t]{2}{*}{ Sig. } \\
\hline & $\mathrm{B}$ & Std. Error & & & \\
\hline 1 (Constant) & 1.62236 & .40769 & & 3.97940 & .00022 \\
\hline $\mathrm{CR}$ & -.00011 & .00038 & -.03907 & -.28948 & .77339 \\
\hline DER & -.00025 & .00087 & -.04401 & -.29134 & .77197 \\
\hline ROE & .00269 & .00133 & .25497 & 2.02062 & .04858 \\
\hline TATO & .04780 & .07784 & .06886 & .61412 & .54187 \\
\hline EPS & .00021 & .00014 & .17046 & 1.50938 & .13737 \\
\hline Suku Bunga & .08158 & .14753 & .15545 & .55296 & .58270 \\
\hline Inflasi & -.11802 & .04770 & -.44708 & -2.47426 & .01672 \\
\hline Kurs & -.00012 & .00006 & -.54935 & -2.21030 & .03160 \\
\hline
\end{tabular}

Berdasarkan Tabel 2. maka dapat dirumuskan persamaan linier berganda, sebagai berikut:

$$
\begin{aligned}
Y=\quad & 1,62236-0,00011 X_{1}-0,00025 X_{2}+0,00269 X_{3}+0,04780 X_{4}+0,00021 X_{5} \\
& +0,08158 X_{6}-0,11802 X_{7}-0,00012 X_{8}+e \ldots \ldots \ldots \ldots \ldots \ldots \ldots \ldots \ldots \ldots \ldots \ldots \ldots \ldots \ldots \ldots \ldots
\end{aligned}
$$

Berdasarkan persamaan diatas dapat dijelaskan sebagai berikut: (1) Variabel CR memiliki nilai koefisien regresi sebesar - 0,00011, berarti bahwa apabila CR naik 1 persen, maka return saham akan turun sebesar 0,00011 persen dengan asumsi bahwa variabel lain konstan. (2) Variabel DER memiliki nilai koefisien regresi sebesar - 0,00025, berarti bahwa apabila DER naik 1 persen, maka return saham akan turun sebesar 0,00025 persen dengan asumsi bahwa variabel lain konstan. (3)Variabel ROE memiliki nilai koefisien regresi sebesar 0,00269, berarti bahwa apabila ROE naik 1 persen, maka return saham akan naik sebesar 0,00269 persen dengan asumsi bahwa variabel lain konstan. (4) Variabel TATO memiliki nilai koefisien regresi 0,04780 , berarti bahwa apabila TATO naik 1 kali, maka return saham akan naik sebesar 0,04780 kali dengan asumsi bahwa variabel lain konstan. (5) Variabel EPS memiliki nilai koefisien regresi sebesar 0,00021, berarti 
bahwa apabila EPS naik 1 rupiah, maka return saham akan naik sebesar 0,00021 rupiah dengan asumsi bahwa variabel lain konstan. (6) Variabel suku bunga memiliki nilai koefisien regresi sebesar 0,08158, berarti bahwa apabila suku bunga naik 1 persen, maka return saham akan naik sebesar 0,08158 persen dengan asumsi bahwa variabel lain konstan. (7) Variabel inflasi memiliki nilai koefisien regresi sebesar - 0,11802, berarti bahwa apabila inflasi naik 1 persen, maka return saham akan turun sebesar 0,11802 persen dengan asumsi bahwa variabel lain konstan. (8) Variabel nilai kurs memiliki nilai koefisien regresi sebesar - 0,00012, berarti bahwa apabila nilai kurs naik 1 rupiah, maka return saham akan turun sebesar 0,00012 rupiah dengan asumsi bahwa variabel lain konstan.

Tabel 3.

Hasil Uji Normalitas

\begin{tabular}{cc}
\hline & Unstandardized Residual \\
\hline $\mathrm{N}$ & 60 \\
Kolmogorov-SmirnovZ & 0.816 \\
Asymp. Sig.(2-tailed) & 0.519 \\
\hline
\end{tabular}
Sumber: Data diolah, 2017

Berdasarkan Tabel 3. dapat dilihat bahwa nilai Kolmogorov-Smirnov (K-S) sebesar 0,816, sedangkan nilai Asymp. Sig. (2-tailed) sebesar 0,519. Data pada tabel 2 diketahui bahwa model persamaan regresi telah berdistribusi normal.

Tabel 4.

Hasil Uji Multikolinearitas

\begin{tabular}{ccc}
\hline \multirow{2}{*}{ Model } & \multicolumn{2}{c}{ Colinearity Statistics } \\
\cline { 2 - 3 } & Tolerance & VIF \\
\hline CR & .61204 & 1.63388 \\
DER & .48863 & 2.04656 \\
ROE & .70030 & 1.42796 \\
TATO & .88694 & 1.12747 \\
EPS & .87426 & 1.14382 \\
Suku Bunga & .14109 & 7.08787 \\
Inflasi & .34151 & 2.92815 \\
Kurs & .18051 & 5.53984 \\
\hline
\end{tabular}

Sumber: Data diolah, 2017 
Berdasarkan Tabel 4. dapat dilihat bahwa nilai tolerance variabel CR, DER, ROE, TOTA, EPS, suku bunga, inflasi, nilai kurs lebih besar dari 0,10 dan nilai VIF lebih kecil dari 10 sehingga model regresi telah bebas dari multikolinearitas.

Tabel 5.

Hasil Uji Autokorelasi

\begin{tabular}{cccccc}
\hline Model & $\mathbf{R}$ & $\boldsymbol{R}$ Square & $\begin{array}{c}\text { Adjusted } \boldsymbol{R} \\
\text { Square }\end{array}$ & $\begin{array}{c}\text { Std.Error of the } \\
\text { Estimate }\end{array}$ & $\begin{array}{c}\text { Durbin- } \\
\text { Watson }\end{array}$ \\
\hline 1 & $.657^{\mathrm{a}}$ & .431 & .342 & .263865 & 2.041 \\
\hline Sumber: Data diolah, 2017 & & & &
\end{tabular}

Berdasarkan Tabel 5. dapat dilihat bahwa nilai Durbin-Watson (D-W) sebesar 2,041 dengan nilai dU untuk 60 sampel dan 8 variabel bebas adalah 1,8939 dan nilai 4-dU adalah 2,1061. Oleh karena nilai dU < DW < 4-dU (1,8939 $<2,041<2,1061$ ), maka dari pengujian dengan Durbin-Watson (D-W) dapat diketahui model regresi tidak terdapat gejala autokorelasi.

Tabel 6.

Hasil Uji Heteroskedastisitas

\begin{tabular}{ccc}
\hline Model & $\mathbf{t}$ & Sig. \\
\hline 1 (Constant) & .72264 & .47320 \\
CR & .42619 & .67177 \\
DER & 1.59372 & .11718 \\
ROE & .18071 & .85731 \\
TATO & -.40897 & .68428 \\
EPS & -.55062 & .58430 \\
Suku Bunga & 1.39475 & .16914 \\
Inflasi & -.93657 & .35339 \\
Kurs & -1.85777 & .06898 \\
\hline
\end{tabular}

Sumber: Data diolah, 2017

Berdasarkan Tabel 6. dapat dilihat bahwa tingkat signifikansi CR, DER, ROE, TATO, EPS, suku bunga, inflasi, dan nilai kurs lebih besar dari 0,05 sehingga data yang digunakan terbebas dari gejala heteroskedastisitas. 
Tabel 7.

Hasil Uji Keterandalan Model (Uji F)

\begin{tabular}{rlcc}
\hline & Model & F & Sig. \\
\hline 1 & Regresion & 4.835 & $.000^{\mathrm{a}}$ \\
& Residual & & \\
& Total & &
\end{tabular}

Berdasarkan Tabel 7. diketahui nilai Sig. $=0,000$ yang lebih kecil dari $\alpha=$ 0,05 sehingga model regresi berganda yang digunakan telah memenuhi uji kelayakan model.

Berdasarkan Tabel 2. dapat dijelaskan hasil masing-masing variabel independen terhadap variabel dependen sebagai berikut: Pada pengujian hipotesis pertama, hasil uji parsial diperoleh nilai signifikan sebesar 0,77339 dan nilai koefisien regresi sebesar -0,00011. Nilai signifikansi tersebut lebih besar dari taraf signifikansi 0,05 sehingga hipotesis $\mathbf{H}_{\mathbf{1}}$ ditolak. Pada pengujian hipotesis keduaa, hasil uji parsial, diperoleh nilai signifikan sebesar 0,77197 dan nilai koefisien regresi sebesar $-0,00025$. Nilai signifikansi tersebut lebih besar dari taraf signifikansi 0,05 sehingga hipotesis $\mathbf{H}_{2}$ ditolak. Pada pengujian hipotesis ketiga, hasil uji parsial, diperoleh nilai signifikan sebesar 0,04858 dan nilai koefisien regresi sebesar 0,00269. Nilai signifikansi tersebut lebih kecil dari taraf signifikansi 0,05 sehingga hipotesis $\mathbf{H}_{3}$ diterima. Pada pengujian hipotesis keempat, hasil uji parsial, diperoleh nilai signifikan sebesar 0,54187 dan nilai koefisien regresi sebesar 0,04780. Nilai signifikansi tersebut lebih besar dari taraf signifikansi 0,05 sehingga hipotesis $\mathbf{H}_{\mathbf{4}}$ ditolak. Pada pengujian hipotesis kelima, hasil uji parsial, diperoleh nilai signifikan sebesar 0,13737 dan nilai koefisien regresi sebesar 0,00021. Nilai signifikansi tersebut lebih besar dari taraf 
signifikansi 0,05 sehingga hipotesis H5 ditolak. Pada pengujian hipotesis keenam, hasil uji parsial diperoleh nilai signifikan sebesar 0,58270 dan nilai koefisien regresi sebesar 0,08158. Nilai signifikansi tersebut lebih besar dari taraf signifikansi 0,05 sehingga hipotesis $\mathbf{H}_{6}$ ditolak. Pada pengujian hipotesis ketujuh, hasil uji parsial, diperoleh nilai signifikan sebesar 0,01672 dan nilai koefisien regresi sebesar - 0,11802. Nilai signifikansi tersebut lebih kecil dari taraf signifikansi 0,05, sehingga $\mathbf{H}_{7}$ diterima. Pada pengujian hipotesis kedelapan, hasil uji parsial, diperoleh nilai signifikan sebesar 0,03160 dan nilai koefisien regresi sebesar - 0,00012. Nilai signifikansi tersebut lebih kecil dari taraf signifikansi 0,05, sehingga $\mathbf{H}_{8}$ ditolak

Tabel 8.

Hasil Uji Koefisien Determinasi $\left(\mathbf{R}^{2}\right)$

\begin{tabular}{ccccc}
\hline Model & $\mathbf{R}$ & $\boldsymbol{R}$ Square & $\begin{array}{c}\text { Adjusted } \boldsymbol{R} \\
\text { Square }\end{array}$ & $\begin{array}{c}\text { Std.Error of the } \\
\text { Estimate }\end{array}$ \\
\hline 1 & $.657^{\mathrm{a}}$ & .431 & .342 & .263865 \\
\hline
\end{tabular}

Sumber: Data diolah, 2017

Berdasarkan Tabel 8. dapat diketahuin koefisien determinasi dengan adjusted $\mathrm{R}^{2}$ sebesar 0,342. Nilai ini menunjukkan bahwa 34,2 persen variasi return saham dapat dijelaskan oleh variabel bebasnya, yaitu CR, DER, ROE, TATO, EPS, suku bunga, inflasi, dan nilai kurs rupiah. Sisanya sebesar 65,8 persen dijelaskan oleh variabel lain diluar model penelitian.

Hasil pengujian statistik pada CR secara parsial menunjukkan adanya pengaruh negatif dan tidak signifikan terhadap return saham perusahaan sub sektor food and beverage di BEI periode 2012-2016. Berdasarkan hasil penelitian dapat diketahui tingginya $\mathrm{CR}$ mengindikasikan adanya indle fund (dana menganggur) yang tinggi pula, yang mencerminkan perusahaan kurang mampu 
mengoperasikan aktiva lancarnya sehingga dapat menimbulkan opportunity lost (hilangnya kesempatan). Hal ini menunjukkan bahwa investor akan memperoleh return saham yang lebih rendah jika kemampuan perusahaan dalam memenuhi kewajiban jangka pendeknya tinggi. Berdasarkan hasil analisa signifikansi dapat diketahui nilai $\mathrm{CR}$ perusahaan menunjukkan adanya hubungan tidak signifikan atau tidak berpengaruh nyata terhadap peningkatan return saham, yang memiliki arti bahwa investor cenderung tidak mempertimbangkan nilai CR dalam mengambil keputusan investasi yang dapat mempengaruhi return saham, sehingga penurunan return saham tidak dipengaruhi secara nyata oleh peningkatan nilai CR. Hasil ini sesuai temuan Malintan (2012) dan Thrisye dan Nicodemus (2013) yang menunjukkan bahwa CR berpengaruh negatif dan tidak signifikan terhadap return saham.

Hasil pengujian statistik pada DER secara parsial menunjukkan adanya pengaruh negatif dan tidak signifikan terhadap return saham perusahaan sub sektor food and beverage di BEI periode 2012-2016. DER yang tinggi mencerminkan bahwa struktur permodalan perusahaan lebih banyak menggunakan utang dibandingkan modal sendiri. Sudut pandang investor menilai bahwa perusahaan yang memiliki nilai DER yang semakin tinggi, maka akan meningkatkan risiko atas utang perusahaan terhadap pihak ketiga (kreditur) dan harus dibebankan kepada perusahaan dengan menggunakan total ekuitas apabila perusahaan mengalami kerugian (Abdullah et al. 2015). Tingkat utang yang semakin tinggi juga menyebabkan beban bunga semakin besar dan akan mengurangi keuntungan yang dimiliki oleh perusahaan. Hal tersebut cenderung 
membuat investor untuk menghindari berinvestasi pada perusahaan yang memiliki nilai DER tinggi. Hasil ini sesuai temuan Allozi dan Obeidat (2016), Bararoh (2015), Malintan (2012) dan Puspitadewi dan Henny (2016) yang menunjukkan bahwa DER berpengaruh negatif dan tidak signifikan terhadap return saham.

Hasil pengujian statistik pada ROE secara parsial menunjukkan adanya pengaruh positif dan signifikan terhadap return saham perusahaan sub sektor food and beverage di BEI periode 2012-2016. Nilai ROE perusahaan yang tinggi menggambarkan perbandingan laba bersih yang diperoleh perusahaan atas total modal sendiri yang ditanamkan juga semakin tinggi sehingga kemampuan perusahaan menggunakan ekuitas dalam menghasilkan laba semakin efektif (Wijesundera et al. 2015). Kondisi ini dapat menyebabkan investor cenderung tertarik untuk memiliki saham perusahaan. Hal ini mengakibatkan peningkatan permintaan saham perusahaan tersebut. Permintaan saham yang meningkat akan sebanding dengan meningkatnya harga dan return saham. Hasil ini sesuai temuan Khan et al. (2013), Indraswari dan Santi (2013), Wijesundera et al. (2015), Saleh (2015), Har dan Muhammad (2015), Allozi dan Obeidat (2016) dan Haghiri (2012) yang menunjukkan bahwa ROE berpengaruh positif dan signifikan terhadap return saham.

Hasil pengujian statistik pada TATO secara parsial menunjukkan adanya pengaruh positif dan tidak signifikan terhadap return saham perusahaan sub sektor food and beverage di BEI periode 2012-2016. Nilai perubahan TATO yang besar dapat diartikan perusahaan memiliki kemampuan untuk menjual produkproduknya dengan cepat. Semakin cepatnya perputaran aset perusahaan 
mengindikasikan bahwa perusahaan memiliki potensi yang besar untuk mendapatkan keuntungan dan mengalami pertumbuhan, sehingga dapat menarik minat investor. Berdasarkan hasil analisa signifikansi dapat diketahui nilai TATO perusahaan menunjukkan adanya hubungan tidak signifikan atau tidak berpengaruh nyata terhadap peningkatan return saham. Hal ini mengindikasikan bahwa investor cenderung tidak mempertimbangkan nilai TATO dalam mengambil keputusan investasi yang dapat mempengaruhi return saham, sehingga peningkatan return saham tidak dipengaruhi secara nyata oleh peningkatan nilai TATO. Hasil ini sesuai temuan Thrisye dan Nicodemus (2013) yang menunjukkan bahwa TATO berpengaruh positif dan tidak signifikan terhadap return saham.

Hasil statistik pada EPS secara parsial menunjukkan adanya pengaruh positif dan tidak signifikan terhadap return saham perusahaan sub sektor food and beverage di BEI periode 2012-2016. Nilai EPS yang tinggi mencerminkan bahwa semakin tinggi tingkat keuntungan yang diperoleh oleh investor atas lembar saham yang dimilikinya. Nilai EPS yang tinggi menunjukkan kinerja perusahaan baik, sehingga dapat menarik investor untuk menginvestasikan dananya pada perusahaan karena dengan EPS yang semakin besar, akan berdampak pada meningkatnya return saham perusahaan. Berdasarkan hasil analisa signifikansi dapat diketahui nilai EPS perusahaan menunjukkan adanya hubungan tidak signifikan atau tidak berpengaruh nyata terhadap peningkatan return saham. Hal ini mengindikasikan bahwa investor cenderung tidak mempertimbangkan nilai EPS dalam membuat keputusan investasi. Hasil ini sesuai temuan Utami et al. 
Kadek Windi Andyani, Pengaruh Variabel Mikro dan...

(2015), Gunarianto (2012), Purnamasari dkk. (2014) dan Wahyuni dkk. (2014) yang menunjukkan bahwa EPS berpengaruh positif dan tidak signifikan terhadap return saham.

Hasil pengujian statistik pada suku bunga secara parsial menunjukkan adanya pengaruh positif dan tidak signifikan terhadap return saham perusahaan sub sektor food and beverage di BEI periode 2012-2016. Suku bunga yang tinggi dapat menyebabkan investor menarik investasinya pada saham dan memindahkannya pada investasi berupa tabungan ataupun deposito, dan menyebabkan menurunnya return saham perusahaan. Hasil yang berbeda ditemukan dalam penelitian ini yaitu peningkatan suku bunga akan diikuti peningkatan return saham, sehingga dapat diketahui investor umumnya tidak mempertimbangkan faktor suku bunga dalam mengambil keputusan investasi. Hasil ini sesuai temuan Dwialesi dan Darmayanti (2016) yang menunjukkan bahwa suku bunga berpengaruh positif dan tidak signifikan terhadap return saham.

Hasil pengujian statistik pada inflasi secara parsial berpengaruh negatif dan signifikan terhadap return saham perusahaan sub sektor food and beverage di BEI periode 2012-2016. Inflasi adalah kecenderungan terjadinya peningkatan harga produk-produk secara keseluruhan sehingga terjadinya penurunan daya beli uang. Inflasi memiliki dampak negatif terhadap harga saham karena inflasi meningkatkan pendapatan dan biaya suatu perusahaan, apabila peningkatan biaya produksi lebih tinggi dari pada pendapatan perusahaan, maka profitabilitas perusahaan tersebut akan mengalami penurunan. Penurunan laba dari perusahaan 
akan menyebabkan investor tidak tertarik untuk berinvestasi pada perusahaan, hal ini dapat mengakibatkan penurunan harga saham dan return. Hasil ini sesuai temuan Utami et al. (2015), Khan et al. (2012), Zhu Bing (2012), dan Karim (2015) yang menunjukkan bahwa inflasi berpengaruh negatif dan signifikan terhadap return saham.

Hasil pengujian statistik pada nilai kurs secara parsial berpengaruh negatif dan signifikan terhadap return saham perusahaan sub sektor food and beverage di BEI periode 2012-2016. Kurs adalah nilai suatu mata uang relatif terhadap mata uang lain. Dollar Amerika sering digunakan sebagai pilihan dalam berinvestasi oleh investor, karena nilai tukar dollar Amerika relatif stabil dan merupakan mata uang yang paling banyak beredar di masyarakat dibandingkan dengan mata uang lainnya. Peningkatan dollar Amerika akan meningkatkan biaya yang harus dibayarkan perusahaan emiten atas hutang luar negerinya baik untuk pembiayaan produksi dan operasional lainnya, hal tersebut akan menurunkan laba perusahaan dan menurunkan harga saham dan return saham. Hasil ini sesuai dengan temuan Bararoh (2015) yang menunjukkan bahwa nilai kurs berpengaruh negatif dan signifikan terhadap return saham.

\section{SIMPULAN DAN SARAN}

Berdasarkan uraian diatas, maka dapat ditarik beberapa simpulan yaitu: (1) CR memiliki pengaruh negatif dan tidak signifikan terhadap return saham perusahaan food and beverage di Bursa Efek Indonesia (BEI) periode 2012-2016; (2) DER memiliki pengaruh negatif dan tidak signifikan terhadap return saham food and beverage di Bursa Efek Indonesia (BEI) periode 2012-2016; (3) ROE 
memiliki pengaruh positif dan signifikan terhadap return saham perusahaan food and beverage di Bursa Efek Indonesia (BEI) periode 2012-2016; (4) TATO memiliki pengaruh positif dan tidak signifikan terhadap return saham perusahaan food and beverage di Bursa Efek Indonesia (BEI) periode 2012-2016; (5) EPS memiliki pengaruh positif dan tidak signifikan terhadap return saham perusahaan food and beverage di Bursa Efek Indonesia (BEI) periode 2012-2016; (6) Suku Bunga memiliki pengaruh positif dan tidak signifikan terhadap return saham perusahaan food and beverage di Bursa Efek Indonesia (BEI) periode 2012-2016; (7) Inflasi memiliki pegaruh negatif dan signifikan terhadap return saham perusahaan food and beverage di Bursa Efek Indonesia (BEI) periode 2012-2016; (8) Nilai Kurs memiliki pengaruh negatif dan signifikan terhadap return saham perusahaan food and beverage di Bursa Efek Indonesia (BEI) periode 2012-2016.

Saran yang dapat diberikan berdasarkan hasil dari penelitian yang dilakukan yaitu: (1) Bagi investor perlu memperhatikan analisis fundamental dan teknikal diantaranya adalah ROE dan inflasi mengingat variabel tersebut memiliki pengaruh signifikan terhadap return saham. (2) Berdasarkan hasil penelitian ini masih terdapat hasil-hasil yang bertentangan dengan teori, sehingga penelitian kedepannya dapat dilakukan kembali dengan menambah variabel-variabel lain yang dapat mempengaruhi return saham dan mengganti periode tahun penelitian sehingga mendapatkan hasil yang akurat.

\section{REFERENSI}

Abdullah, MN., Kamruddin P., Tarana K., and Rahat BT. 2015. The Impact Of Financial Leverage And Market Size On Stock Returns On The Dhaka Stock Exchange: Evidence From Selected Stocks In The Manufacturing 
Sector. International Journal of Economics, Finance and Management Sciences, 3(1) : 10-15.

Aga, Bahram Shadkam,. Vahid Farzin Mogaddam,. Behnam Samadiyan. 2013. Relationship Between Liquidity And Stock Returns In Companies In Tehran Stock Exchange. Applied mathematics in engineering. Management and Technology I, 1(4) : 278-285.

Ali, Syed Atif and Amir Razi. 2012. Impact of Campanies Internal Variables on Stock Prices: A Case Study of Major Industries of Pakistan. Internasional Conference on Education, Applied scienced and Management : 141-144.

Allozi, Nurah Musa and GhassanLS. Obeidat. 2016. The Relatioship between the Stock Return and Financial Indicators (Profitability and Leverage): An Empirical Study on Manufacturing Companies Listed in Amman Stock Exchange. Journal of Social Sciences (COES\&RJ-JSS), 5(3) : 408-424.

Anwaar, Maryyam. 2016. Impact of Firm's Performance on Stock Return (Evidence from Listed Companies of FTSE-100 Index London, UK). Global Journal of Management and Business Research, 16(1) : 31-39.

Bararoh, Tantri. 2015. Analysis of Fundamental Factors, Foreign Exchange and Interest Rate on Stock Return (Studies in Manufacturing Companies Listed on Indonesia Stock Exchange for 2011-2013 periods). International Journal of Business and Management Invention, 4(2) : 36-42.

Bodie, Zvi., Alex Kane, Alan J. Marcus. 2009. Investment. Buku Dua. Edisi Enam. Jakarta: Selemba Empat.

Darmadji, Tjiptono dan Hendy M. Fakhurddin. 2012. Pasar Modal Di Indonesia Edisi 3. Jakarta: Salemba Empat.

Dwialesi, Juanita Bias., dan Ni Putu Ayu Darmayanti. 2016. Pengaruh FaktorFaktor Fundamental Terhadap Return Saham Indeks Kompas 100. E-Jurnal Manajemen, 5(4) : 2545-2572.

Fahmi, Irham. 2012. Manajemen Investasi. Banda Aceh: Selemba Empat.

Farkhan dan Ika. 2012. Pengaruh Rasio Keuangan Terhadap Return Saham Perusahaan Manufaktur Di Bursa Efek Indonesia (Studi Kasus Pada Perusahaan Manufaktur Sektor Food And Beverage). Jurnal Value Added, 9(1) : 1-18.

Firmansyah, Muhammad. 2015. Analisis Pengaruh Inflasi, Nilai Tukar Bunga, dan Pertumbuhan Ekonomi terhadap Return Saham (Studi Kasus pada PT. Semen Indonesia,Tbk. Periode 2005-2014). Jurnal Ilmiah Mahasiswa FEB Universitas Brawijaya, 3(2) : 1-15. 
Gideon, Arthur. 2015. Industri Berbahan Baku Impor Paling Terpukul. http: news.liputan6.com/read/2262001/industri-berbahan-baku-impor-palingterpukul. Diakses tanggal 24, bulan November, tahun 2017.

Gunarianto. 2012. Analisis Earning Per Share Dan Return On Equity Serta Tingkat Bunga Deposito Terhadap Harga Saham Perbankan Di Bursa Efek Indonesia. Jurnal Manajemen dan Akuntansi, 1(2) : 31-42.

Haghiri, Amir and Soleyman Haghiri. 2012. The Investigation of Effective Factors on Stock Return with Emphasis on ROA and ROE Ratios in Tehran stock exchange (TSE). Journal of Basic and Applied Scientific Research, 2(9) : 9097-9103.

Hanafi, Mamduh M. 2014. Manajemen Risiko. Edisi ke 2. Yogyakarta: UPP TIM YKPN.

Har, Wong Pik and Muhammad Afif. 2015. The Impact of Accounting Earning on Stock Return: The Case of Malaysia's Plantation Industry. Internasional Journal of Business and Management, 10(4) : 155-165.

Harahap, Sofian Safri. 2010. Analisis Kritis Atas Laporan Keuangan. Jakarta: Rajawali Persada.

Hartono, Jogiyanto. 2011. Teori Portofolio dan Analisis Investasi. Yogyakarta: BPFE-Yogyakarta.

Ibrahim, Taofik Mohammed and Omosola M. Agbaje. 2013. The Relationship Between Stock Return and Inflation in Nigeria. European Scientific Journal, $9(4): 146-157$.

Indraswari, A.A. Ayu Raras dan Ni Putu Santi Suryantini. 2013. Pengaruh Kondisi Ekonomi, Kondisi Pasar Modal, dan Kinerja Keuangan terhadap Return Saham pada Perusahaan Automotive and Allied Products di BEI. EJurnal Manajemen Unud, 2(12), : 1597-1616.

Jogianto. 2011. Metode Penelitian Bisnis. Yogyakarta: BPFE.

Kadarni, Nur Tri. 2015. Analisis Pengaruh Current Ratio, Debt To Equity Ratio, Quick Asset To Inventory Ratio dan Return On Asset Terhadap Return Saham. Jurnal Akuntansi \& Keuangan Unja, 2 : 50-64.

Karim, Abdul. 2015. Analisis Pengaruh Faktor Internal dan Eksternal Terhadap Return Saham Perusahaan Manufaktur yang Terdaftar di Bursa Efek Indonesia (BEI) Periode 2010-2012. Media Ekonomi dan Manajemen, 30 (1) : 41-55.

Kasmir. 2012. Analisis Laporan Keuangan. Rajawali Pers : Jakarta. 
2013. Analisis Laporan Keuangan. Rajawali Pers : Jakarta.

Kewal, Suramaya S. 2012. Pengaruh Inflasi, Suku Bunga, Kurs, dan Pertumbuhan PDB Terhadap Indeks Harga Saham Gabungan. Sekolah Tinggi Ilmu Ekonomi Musi Palembang, Indonesia. : 53-64.

Khan, Wajid, Arab Naz, Madiha Khan, Waseem Khan Qaiser Khan, And Shabeer Ahmad. 2013. The Impact of Capital Structure and Financial Perpormance on Stock Returns "A Casevof Pakistan Textile Industry". Middle-East Journal of Scientific Research, 16(2) : 289-295.

Khan, Zohaib, Sangeen Khan, Lala Rukh, Imdadullah, and Wajeeh ur Rehman. 2012. Impact Of Interest Rate, Exchange Rate And Inflation On Stock Returns Of KSE 100 Index. International Journal of Economic Research, $3(5): 142-155$.

Khaza'leh, Saeed Ahmed and Dr. Ghazi Abdul Majeed Alrguibat. 2014. The Impact of Macroeconomic Indicators on Stocks Return for the Jordanian Insurance Companies during the Period (2000-2012). Global Journal of Management and Business Research, 14(5) : 77-85.

Krisna, Anak Agung Gde Aditya dan Ni Gusti Putu Wirawati. 2013. Pengaruh Inflasi, Nilai Tukar Rupiah, Suku Bunga Sbi pada Indeks Harga Saham Gabungan di BEI. E-Jurnal Akuntansi Universitas Udayana, 3(2) : 421-435.

Kurniatun, Maya; Nugraha, Hari Susanta; Saryadi, Saryadi. 2015. Pengaruh Current Ratio (CR), Debt To Equity Ratio (DER), Total Asset Turnover (TAT), Return On Asset (ROA) dan Price Earning Ratio (PER) Terhadap Return Saham (Pada Perusahaan Retail Yang Terdaftar di Bursa Efek Indonesia 2010-2014). Jurnal Ilmiah Administrasi Bisnis, 4(3) : 101-109.

Laporan harga saham yang diakses melalui www.duniainvestasi.com pada tanggal 9 bulan November tahun 2017

Laporan keuangan yang diakses melalui www.idx.co.id pada tanggal 9 bulan November tahun 2017

Laporan tingkat suku bunga, inflasi, dan nilai kurs yang diakses melalui www.bi.go.id pada tanggal 9 bulan November tahun 2017.

Malintan Rio, and Tubandrijah Herawati. 2012. Pengaruh Current Ratio (CR), Debt to Equity Ratio (DER), Price Earning Ratio (PER), dan Return On Asset (ROA) terhadap Return Saham Perusahaan Pertambangan yang Terdaftar di Bursa Efek Indonesia Tahun 2005-2010. Jurnal Ilmiah Fakultas Ekonomi dan Bisnis Universitas Brawijaya, 1(1) : 1-25. 
Nawalani, Arinda Putri dan Wiwik Lestari. 2015. Pengaruh Modal Kerja Terhadap Profitabilitas pada Perusahaan Food And Baverage di Bursa Efek Indonesia. Journal Of Business and Banking, 5(1) : 51-64.

Nurhakim S, Anistia; Irni Yunita, and Aldilla Iradianty. 2016. The Effect Of Profitability And Inflation On Stock Return At Pharmaceutical Industries At Bei In The Period Of 2011-2014. Asia Pacific Journal of Advanced Business and Sosial Studies, 2(2) : $202-210$.

Octafia, Sri Mona. 2013. Pengaruh Tingkat Suku Bunga SBI, Nilai Tukar dan Jumlah Uang Beredar Terhadap Indeks Harga Saham Sektor Property dan Real Estate Dengan Pendekatan Error Correction Model. Jurnal Manajemen, 2(1) : 1-10.

Oshaibat, Suleiman Al and Ahmad Majali. 2016. The Relationship Between Stock Returns And Each Of Inflation, Interest Rates, Share Liquidity And Remittances Of Workers In The Amman Stock Exchange. Journal of Internet Banking and Commerce, 21(2) : 2-17.

Pinka Komala, 2013. The Effects Of Profitability Ratio, Liquidity, and Debt Towards Invesment Return, Academic Star Pubulishing Company. 4(11), ISSN 2155-7950

Purnamasari, Khairani,. Emrinaldi Nur DP,. Aja Adri Satriawan S. 2014. Pengaruh Current Ratio (CR), Debt to Equity Ratio (DER), Return On Equity (ROE), Price Earning Ratio (PER), dan Earning Per Share (EPS) Terhadap Return Saham Pada Perusahaan Property And Real Estate Yang Terdaftar di Bursa Efek Indonesia Tahun 2009-2011. Jom FEKON, 1(2) : 114.

Puspitadewi, Cokorda Istri Indah. Henny Rahyuda. 2016. Pengaruh DER, ROA, PER dan EVA Terhadap Return Saham Pada Perusahaan Food And Beverage Di BEI. E-Jurnal Manajemen Unud, 5(3) : 1429-1456.

Salamat, Wasfi A. Al and Haneen H. H. Mustafa. 2016. The Impact of Capital Structure on Stock Return: Empirical Evidence from Amman Stock Exchange. International Journal of Business and Social Science, 7(9) : 183196.

Saleh, Muhammad. 2015. Relationship between Firm's Financial Perfomance and Stock Return: Evidence form Oil and Gas Sector Pakistan. Journal of Energy Technologies and Policy, 5(10) : 27-32.

Samsul Mohamad. 2006. Pasar Modal \& Manajemen Portofolio. Jakarta: Erlangga. 
Sawir, Agnes. 2009. Analisis Kinerja Keungan dan Perencanaan Keuangan Perusahaan. PT. Gramedia Pustaka Utama, Jakarta.

Setiyawan, Indra. 2014. Pengaruh Current Ratio, Inventory Turnover, Time Interest Earned dan Return On Equity Terhadap Harga Saham Pada Perusahaan Manufaktur Sektor Barang Konsumsi Yang Terdaftar di BEI Periode 2009-2012. Jurnal Nominal, 3(2) : 117-133.

Syamsuddin. 2009. Manajemen Keuangan Perusahaan. Jakarta: PT. Raja Grafindo Persada.

Tandelilin, Eduardus. 2010. Portofolio dan Investasi Teori dan Aplikasi. Yogyakarta: Kanisius.

Thrisye, R. Y., dan Nicodemus Simu. 2013. Analisis Pengaruh Rasio Keuangan Terhadap Return saham BUMN Sektor Pertambangan Periode 2007-2010. Jurnal Ilmiah Akuntansi 8(2).

Ulupui, IGKA. 2007. Analisis Pengaruh Rasio Likuiditas, Leverage, Aktivitas, dan Profitabilitas Terhadap Return Saham (Studi Pada Perusahaan Makanan dan Minuman Dengan Kategori Industri Barang Konsumsi di BEJ). Jurnal Ilmiah Akuntansi dan Bisnis Universitas Udayana.

Utami, Widya Retno, Sri Hartoyo, and Tubagus Nur Ahmad Maulana. 2015. The Effect of Internal and External Factors on Stock Return: Empirical Evidence from the Indonesian Construction Subsector. Asian Journal of Business and Management, 3(5) : 370-377.

Wahyuni, Made Dwi., Ni Luh Gede Erni Sulindawati., Edy Sujana. 2014. Analisis Pengaruh Return On Asset (ROA), Earning Per Share (EPS), dan Residual Income (RI) Terhadap Return Saham Studi Pada Perbankan Yang Go Public Tahun 2009-2012. E-Jurnal Akuntansi Universitas Pendidikan Ganesha, 2(1).

Wiagustini, Ni Luh Putu. 2014. Manajemen Keuangan. Denpasar: Udayanaa University Press.

Wijesundera, A. A. V. I., D. A. S. Weerasinghe, T. P. C. R. Krishna, M. M. D. Gunawardena, and H. R. I. Peiris. 2015. Predictability of Stock returns Using Financial Ratios: Empirical Evidence from Colombo Stock Exchange. Kelaniya Journal of Management, 4(2) : 44-55.

Zhu, Bing. 2012. The Effeect of Macroeconomic Factors on Stock Return of Energy Sector in Shanoghai Stock Market. Internasional Journal of Scienotific and Research Pubulications,S2(11) : 1-4. 